\title{
Diet and Cancer.
}

THERE have been and are all sorts of statements 1 about the relation of diet to the occurrence of cancer. We are told that eating raw carrots will prevent and even cure it; others attribute efficacy to onions, others to a salt-free diet ; tomatoes, on the other hand, have been suspected of causing cancer. Particularly common is the suggestion, which appears at times to have crystallised into a belief, that vegetarians suffer from malignant disease less than ordinary people who take a fleshy diet.

None of these statements has been subjected to critical inquiry; and indeed such inquiry is by no means easy, for it is hard to find two bodies of persons, in other respects wholly comparable, who differ only in their enjoyment or rejection of meat. The vegetarians in Great Britain, for example, could not, without the strictest inquiry, be regarded as a sample of the population which differed from the normal only in their avoidance of meat; there are many grades and subclasses of vegetarians, but, taken as a whole, they form a group distinguished in many modes of life and thought besides their diet. In the world at large, vegetarianism, in short, is generally a character associated with other exceptional features of body and mind, and any advantage or disadvantage which vegetarians may show in the incidence of disease may be due to their general make-up as likely as to the nominal outward sign of it. The study of such associations in man is, indeed, difficult, and is liable to be extremely fallacious.

Particularly welcome, therefore, is the report on the incidence of cancer in certain religious orders by Dr. S. Monckton Copeman and Dr. Major Greenwood. With the co-operation of the ecclesiastical authorities and with an amount of detailed inquiry which must have been even more troublesome than it seems, they have collected the necessary statistics in a number of religious houses in England and elsewhere. 'The

1 Ministry of Health. Reports on Public Health and Medical Subjects, No. 36: Diet and Cancer, with Special Reference to the Incidence of Cancer upon Members of certain Religious Orders. By Dr. S. Monckton Copeman and Major Greenwcod. Pp. iv +33 . (London: H.M. Staticnery Office, 1.926.) $9 d$. net. monks, nuns, and lay brothers in these communities are all essentially vegetarians : but we can be pretty sure that vegetarianism is no more than an incidental circumstance, and that the nature of the diet has had no influence in determining the membership of these communities. Among the Carthusians and Cistercians the rules are especially strict, and a life which is spent in silence in a cell from which the monk comes out only for a nightly service, for a meal in the refectory on Sundays, and for a weekly walk, cannot be said to involve much of that hurry, luxury, and excess to which cancer and other sickness is so often ascribed. But the results of this minute inquiry into their mortality shows that, while perhaps as a whole the mortality is in some instances rather less than would be expected in persons of similar age and sex in the outside world, there is no evidence at all of any immunity to cancer. Thus in a Cistercian house in England, 427 people lived between 1800 and 1920 : there were 104 deaths against an expectation of 82 in the general population, and of these 5 certainly, and 3 probably, died of cancer, as compared with 5 or 6 in non-monks. Cistercian nuns in England and a Belgian house of the same order give similar results, as do Benedictine and Carmelite communities in which the rules are not quite so strict. Taken separately or together, the figures lend no support to a proposition that cancer is either less or more common inside monasteries than among the contemporary comparable part of the population outside.

Finally, data are given which were. collected less minutely and completely from 57 Cistercian houses in different parts of the world : the figures seem to show a singularly small number of deaths from cancer, but, as the authors point out, the calculations are subject in these instances to so many qualifications that one is once again reduced to the conclusion that there is no evidence of any difference either way. Any one who feels inclined to rush in and solve the problem of the causation of cancer by statistical methods should study carefully this admirable example of how such work should be done : it is much more difficult than some enthusiasts imagine.

\section{Maori Navigation.}

THE vessels used by the peoples of the Pacific in their migrations and colonisations are of primary importance in Oceanic ethnology. They have been described by various writers, but only partially, and generally from the technological side. Now, in an interesting Bulletin of the Dominion Museum of New Zealand, ${ }^{1}$ Mr. Elsdon Best has collected all that is known or can be learned from native sources about Maori canoes. Every aspect of the subject is discussed and fully illustrated by copies of early prints or modern photographs.

Some types of Maori canoes have entirely disappeared. The double canoe, formed by two dugouts united by a platform, survived until about 1830 . The occurrence of the single canoe with one outrigger is denied by some writers, although it is said to have been seen by Captain Cook. The single canoe with double outrigger is said to be only mentioned in tradition. This becomes important when it is noted that Indo-Javan vessels twelve centuries ago had double outriggers.

The only native canoe now used is that without an

1 New Zealand, Dominion Museum. Bulletin No. 7: The Maor Canoe. Ry Ilsdon Best. Published under the direction of the Board Ganoe. By Elsdon Best. Published under the direction of the Board N.Z. : W. A. G. Skinner, 1925.)

No. 2990, Vor. 119] outrigger. The generic name is waka. Varieties are distinguished as the waka taua, war canoe, waka tete used for fishing and travelling, and the waka titai and other small craft used in calm waters.

The building of the waka taua is fully described. The tree, of totara, kauri, or other timber, was reserved by clearing the bush around or by a taboo. A strip of bark might be peeled off one side to initiate decay and facilitate hollowing out. On an auspicious day, after fasting and ritual, the trunk was felled. Sometimes the lower part was scarfed, or the uncovered roots were burned, or an ingenious machine on the ballista principle was used. The trunk was charmed to prevent damage in falling. The hollowing was performed by burning and by the stone adze. Canoe makers wore only one garment, and their food, reserved for them alone, was cooked apart. It was etiquette for a visitor to throw his spear at the canoe. If it stuck, the omen was favourable. The hull was hauled to the water side by ropes, often for long distances, by many people. Charmed skids eased the canoe over rough ground. Sometimes the hull was composed of more than one piece.

The sides of the dug-out were heightened by an ornamental top strake, butted and lashed to its top edge by strings of flax, and caulked with fibre. The 